\title{
PENERAPAN MODEL KOOPERATIF TIPE JIGSAW DALAM PEMBELAJARAN PPKn UNTUK MENINGKATKAN MOTIVASI BELAJAR
}

\author{
${ }^{1}$ Resha Sapti Apriliani \\ ${ }^{2}$ Lusiana Rahmatiani \\ ${ }^{3}$ Erwin Susanto \\ Pendidikan Pancasila dan Kewarganegaraan, Fakultas Keguruan dan Ilmu Pendidikan,
Universitas Buana Perjuangan Karawang
${ }^{{ }^{1} \text { Pk16.reshaaprliani@ mhs.ubpkarawang.ac.id, }},{ }^{2} \underline{\text { lusiana.rahmatiani@ ubpkarawang.ac.id }}$
${ }^{3} \underline{\text { susanto@ ubpkarawang.ac.id }}$
}

\begin{abstract}
ABSTRAK
Penelitian ini bertujuan untuk mengetahui bagaimana peningkatan motivasi belajar siswa dengan di terapkannya model kooperatif tipe jigsaw dalam pembelajaran Pendidikan Pancasila dan Kewarganegaraan (PPKn) pada siswa kelas XI SMK Negeri 2 Karawang. Penelitian ini menggunakan pendekatan kualitatif dengan metode deskriptif. Subjek dalam penelitian ini terdiri dari guru mata pelajaran Pendidikan Pancasila dan Kewarganegaraan (PPKn), siswa dan expert judgement. Teknik pengumpulan data yang peneliti gunakan yaitu wawancara, observasi dan dokumentasi. Adapun teknik analisis yang digunakan ialah triangulasi sumber. Permasalahan yang mendasar dalam penelitan ini adalah rendahnya motivasi belajar yang dimiliki siswa akibat penerapan model pembelajaran yang kurang tepat. Hasil penelitian menunjukan bahwa terdapat peningkatan motivasi belajar siswa saat diterapkannya model kooperatif tipe jigsaw dalam pembelajaran PPKn. Siswa mempunyai gairah untuk mengikuti pembelajaran dengan baik. Kemudian siswa ikut terlibat dalam kegiatan pembelajaran yaitu siswa maupun siswi ikut terlibat dalam kegiatan diskusi, mampu bekerja sama dan saling bertukar fikiran serta mempunyai keberanian untuk mengemukakan pendapatnya. Rekomendasi dari penelitian ini meliputi Pertama, pihak sekolah sebagai pembuat kebijakan diharapkan memberikan adanya kebijakan agar model pembelajaran kooperatif ini dapat terus digunakan dalam kegiatan belajar mengajar. Kedua, pihak sekolah harus menyediakan sarana berupa sumber belajar agar tujuan pembelajaran dapat tercapai. Ketiga, guru hendaknya melakukan pendekatan yang lebih dengan memberikan suport dan arahan kepada siswa agar siswa yang belum siap menerima pembelajaran menjadi lebih termotivasi.
\end{abstract}

Kata kunci: Model Kooperatif Tipe Jigsaw, PPKn, Motivasi Belajar

\begin{abstract}
This research aims to investigate how students' learning motivation increase with the jigsaw method of cooperative learning implementation in the learning process of Pancasila and Civics Education ( $P P K n)$ in $11^{\text {th }}$-grade students of SMK Negeri 2 Karawang. This research used a qualitative approach with a descriptive method. The subjects of this research are the teachers of Pancasila and Civics Education $(P P K n)$, students, and expert judgment. The data collection techniques used in this research are interviews, observations, and context documentations. The data analysis method used in this research is source triangulation. The main problem of this research is the lack of students' learning motivation that is caused by the implementation of the ineffective learning model. The result of research indicates that there is an increase in students' learning motivation during the jigsaw method of cooperative
\end{abstract}


learning implementation in the learning process of PPKn. Students have more interest to follow the class diligently. Additionally, students participated in various learning activities. They take part in class discussions, can work cooperatively, share their thoughts, and also have the courage to voice out their opinions. There are several recommendations from this research. First, the school as a policymaker is expected to create a policy in which this cooperative learning model can be used regularly in class. Second, the school should provide learning resources as the facilities therefore the learning objectives can be achieved. Third, teachers should make a more intensive approach by providing support and guidance to students therefore students who are not ready to follow the class become more motivated.

Keywords: Jigsaw Method of Cooperative Learning, PPKn. Learning Motivation

\section{PENDAHULUAN}

Pendidikan adalah proses pembelajaran secara langsung maupun tidak langsung antara seseorang maupun golongan yang dengan sengaja atau tidak sengaja melakukan kegiatan pembelajaran, baik di suatu ruangan maupun secara terbuka untuk menambahkan ilmu pengetahuan kepada seseorang yang belum paham akan pendidikan itu (Neolaka, 2017: 12). Pendidikan merupakan usaha sadar yang terencana yang dilakukan dalam proses pembelajaran, selain untuk memahami pengetahuan peserta didik diharapkan mampu mengembangkan potensi dirinya.

Mata pelajaran PPKn adalah mata pelajaran wajib di setiap jenjang pendidikan di Indonesia. Salah satu tujuan PPKn yang diatur dalam Permendiknas Nomor 22 Tahun 2006 tentang Standar Isi untuk Satuan Pendidikan Dasar dan Menengah, yaitu adalah siswa di harapkan mampu berfikir secara kristis, rasional dan kreatif dalam menanggapi isu kewarganegaran. Dalam pembelajaran PPKn, masih banyak siswa yang menganggap pembelajaran PPKn adalah pembelajaran yang penuh dengan teori dan fakta-fakta. Perlu adanya upaya guru untuk menciptakan proses pembelajaran yag menarik, agar siswa dapat tertarik dan termotivasi dalam pembelajaran PPKn.

Guru dianggap sebagai fasilitator antara materi pembelajaran dengan siswa. Guru diibaratkan seperti orang yang memberi arah jalan atas keberhasilan proses pembelajaran. Dalam proses pembelajaran tentunya terdapat beberapa faktor yang mempengaruhi keberhasilan pembelajaran, salah satunya yaitu motivasi belajar. Suprihatin (2015) menyatakan bahwa proses pembelajaran akan berhasil manakala siswa mempunyai motivasi dalam belajar. Menurut Suprihatin dalam Hakim (2007:26), motivasi adalah suatu dorongan kehendak yang menyebabkan seseorang melakukan suatu perbuatan untuk mencapai tujuan tertentu. Motivasi merupakan salah satu faktor yang sangat berpengaruh dalam keberhasilan siswa dalam 
pembelajaran. Motivasi belajar merupakan syarat mutlak untuk belajar dan memegang peranan penting dalam memberikan gairah atau semangat dalam belajar (Kusuma \& Subhan, 2015). Oleh karena itu perlu adanya upaya guru dalam meningkatkan motivasi belajar siswa khususnya dalam pembelajaran PPKn.

Salah satu upaya guru untuk menumbuhkan motivasi belajar siswa yaitu dengan cara menggunakan model pembelajaran yang sesuai dengan materi yang diajarkan. Model pembelajaran yang dapat di terapkan adalah model pembelajaran kooperatif. Pembelajaran kooperatif merupakan bentuk pembelajaran dengan cara siswa belajar dan bekerja dalam kelompok-kelompok kecil secara kolaboratif yang anggotanya terdiri dari empat sampai enam orang dengan struktur kelompok yang bersifat heterogen, (Rusman,2016:202). Salah satu model pembelajaran kooperatif yang dapat melibatkan siswa dan menumbuhkan motivasi dalam pembelajaran adalah model kooperatif tipe Jigsaw. Model Jigsaw mengikuti pola kerja sebuah gergaji (zigzag) yang artinya siswa diharapkan mampu melakukan suatu proses pembelajaran dengan cara bekerja sama dengan siswa lain untuk mencapai tujuan pembelajaran yang telah ditentukan. (Rusman,2016:217).

Berdasarkan timbulnya permasalahan di atas peneliti menemukan beberapa faktor permasalahan yang terjadi pada saat proses pembelajaran, salah satunya yaitu rendahnya motivasi belajar siswa, dalam proses pembelajaran berlangsung peneliti melihat hanya ada beberapa siswa yang ikut terlibat aktif dalam proses pembelajaran. Hal itu dikarenakan penerapan model pembelajaran yang kurang tepat dan menarik, sehingga kegiatan belajar terasa membosankan. Oleh karena itu perlu adanya upaya guru dalam meningkatkan motivasi belajar siswa salah satunya dengan menerapkan model pembelajaran kooperatif tipe Jigsaw. Melihat dari permasalahan yang telah diuraikan, maka peneliti melakukan penelitian yang berjudul "Penerapan Model Kooperatif Tipe Jigsaw Dalam Pembelajaran PPKn Untuk Meningkatkan Motivasi Belajar Siswa.

\section{METODE PENELITIAN}

Pendekatan yang peneliti gunakan ialah pendekatan kualitatif dengan metode deskriptif. Penelitian ini dilakukan pada tanggal 29 april 2020 s/d 14 maret 2020, dan dilaksanakan di sebuah Lembaga Pendidikan SMK Negeri 2 Karawang. Adapun subjek dalam penelitian ini terdiri dari guru PPKn, siswa dan expert judgement. Prosedur penelitian yang peneliti gunakan yaitu tahap deskripsi, tahap reduksi dan tahap seleksi. Kemudian teknik pengumpulan data 
yang digunakan ialah observasi, wawancara dan studi dokumentasi. Dan dalam teknik analisis data peneliti menggunakan triangulasi sumber.

\section{HASIL PENELITIAN DAN PEMBAHASAN}

Berdasarkan data yang diperoleh melalui wawancara, obervasi dan studi dokumentasi. Pada bagian ini akan dikemukakan hasil dan pembahasan terkait motivasi belajar siswa dengan di terapkannya model pembelajaran kooperatif tipe jigsaw dalam pembelajaran PPKn.

\section{Motivasi belajar siswa dengan di terapkannya model kooperatif tipe jigsaw dalam pembelajaran PPKn di SMK Negeri 2 Karawang.}

Sebagaimana dipahami bersama bahwa motivasi belajar merupakan faktor penting dalam keberhasilan pembelajaran seorang siswa. Siswa harus bisa memotivasi dirinya sendiri, akan tetapi guru sebagi pengajar juga mempunyai peranan penting dalam menumbuhkan motivasi dan semangat belajar siswa, salah satunya dengan menerapkan model pembelajaran yang tepat. Hal ini sejalan dengan pernyataan Dimyati \& Mudjiono (2015:43), yang mengatakan bahwa motivasi dapat bersifat internal, artinya datang dari dirinya sendiri, dapat juga bersifat eksternal yaitu datang dari orang lain, dari guru, orang tua, teman, dan sebagainya.

Berdasarkan hasil penelitian yang di lakukan bagaimana motivasi belajar siswa dengan di terapkannya model kooperatif tipe jigsaw dalam pembelajaran PPKn, menunjukan bahwa pada saat diterapkannya model pembelajaran kooperatif tipe jigsaw, ada peningkatan motivasi yang di miliki siswa, yakni siswa terlihat mempunyai gairah untuk mengikuti pembelajaran dengan baik serta siswa merasakan suasana pembelajaran yang berbeda jika dibandingkan dengan pembelajaran sebelumnya yang tidak menggunakan model pembelajaran jigsaw. Pada saat pembelajaran berlangsung setiap siswa maupun siswi dilibatkan dalam kegiatan diskusi sehingga tercipta suasana interaktif dan kompetitif, yang berarti siswa saling aktif bukan hanya untuk dirinya sendiri tetapi juga kelompok. Hal ini sesuai dengan pernyataan Abdullah (2017), bahwa pembelajaran kooperatif tipe jigsaw mempunyai kelebihan, yaitu :

a. Dapat menumbuhkan semangat kerja sama dan kegairahan dalam belajar bagi siswa.

b. Meningkatkan motivasi, saling menghargai antara sesama siswa.

c. Memberikan peluang untuk menyampaikan gagasan secara terbuka karena jumlah siswa yang terbatas dalam setiap kelompok.

d. Melatih siswa agar mampu berkomunikasi secara efektif. 
Dikarenakan dalam pembelajaran kooperatif tipe jigsaw ini merupakan pembelajaran dari teman sendiri, dan peran guru yang terus membimbing dan memberikan motivasi pada siswa, maka terdapat pengaruh positif bagi siswa terutama siswa pasif, yaitu siswa pasif mempunyai peningkatan dalam belajarnya. Pada saat pembelajaran berlangsung siswa pasif ikut serta dalam kegiatan diskusi yang secara tidak langsung melatih dirinya untuk mampu bekerja sama dalam bertukar fikiran seta mempunyai rasa percaya diri dan keberanian untuk mengemukakan pendapatnya. Oleh karena itu motivasi belajar sangat berperan penting dalam keberhasilan belajar siswa. Hal ini sejalan dengan pandangan Kusuma dan Subhan (2015), mengatakan bahwa motivasi belajar merupakan syarat mutlak untuk belajar dan memegang peranan penting dalam memberikan gairah atau semangat dalam belajar. Kemudian sesusai dengan pernyataan Lestari (2014) yang mengatakan terdapat sejumlah indikator yang memiliki motivasi belajar dalam proses pembelajaran, diantaranya adalah :

a. Adanya dorongan dan kebutuhan belajar

b. Menunjukan perhatian dan minat terhadap tugas-tugas yang diberikan

c. Tekun menghadapi tugas

d. Ulet menghadapi kesulitan

e. Adanya hasrat dan keinginan berhasil

Pada saat kegiatan belajar mengajar berlangsung suasana kelas menjadi lebih aktif karena siswa ikut berperan dalam proses pembelajaran, yakni berperan dalam kegiatan diskusi. Adapun kegiatan yang melibatkan siswa dalam proses pembelajaran yaitu siswa terlihat antusias dan semangat pada saat pembagian kelompok asal dan kelompok ahli. Setiap anggota kelompok asal mempunyai bagian materi yang berbeda, kemudian tiap anggota kelompok asal membagi diri menjadi kelompok ahli. Kelompok ahli adalah kelompok yang mendiskusikan materi yang perlu dicari jawabannya. Setelah diskusi kelompok selesai maka anggota kelompok ahli kembali ke kelompok asal untuk menyampaikan hasil diskusinya. Sehingga memudahkan siswa untuk lebih memahami materi pembelajaran. Dan terlihat ada peningkatan motivasi siswa terhadap pembelajaran PPKn. Walaupun tidak semua siswa pasif menjadi lebih aktif, akan tetapi ketika pembelajaran menggunakan model jigsaw ini bisa melatih mereka untuk lebih mempunyai rasa percaya diri dalam bertukar fikiran dan mengemukakan pendapatnya.

\section{KESIMPULAN DAN IMPLIKASI}


Motivasi belajar dengan diterapkannya model kooperatif tipe jigsaw dalam pembelajaran PPKn sangat meningkat. Hal ini dapat dilihat ketika kegiatan belajar mengajar berlangsung siswa mampu berfikir kritis dan bekerjasama saling mengemukakan pendapatnya. Kemudian terlihat juga peningkatan motivasi belajar pada siswa yang pasif yakni siswa pasif tersebut mempunyai keberanian dan merasa percaya diri untuk menyampaikan hasil pendapatnya di depan semua teman kelasnya. Walaupun tidak semua siswa pasif menjadi lebih aktif, akan tetapi mereka sudah mempunyai wawasan untuk kedepannya agar menjadi siswa yang lebih aktif serta dapat meningkatkan motivasi belajarnya.

Adapun implikasi yang didapat dari penelitian ini adalah :

Motivasi belajar merupakan salah satu peranan penting dalam proses pembelajaran, sebab adanya motivasi dapat menumbuhkan semangat belajar siswa, dan sebaliknya, ketika tidak adanya motivasi belajar dalam diri siswa maka akan menurun juga dalam semangat belajarnya. Peran yang dilakukan guru selain menjadi fasilitator, guru juga harus menjadi motivator yaitu membangun dan menumbuhkan motivasi belajar siswa, yakni dengan cara memilih model pembelajaran yang tepat dan sesuai dengan materi yang di ajarkan di kelas agar siswa memiliki gairah semanagat dalam belajar serta ikut berperan dalam proses pembelajaran. Jika siswa memiliki motivasi belajar yang tinggi dan ikut berperan dalam kegiatan pembelajaran, maka suasana kelas pun akan menjadi aktif serta pembelajaran akan berjalan dengan maksimal. 


\section{DAFTAR PUSTAKA}

Abdullah, R. 2017. Pengaruh Penerapan Model Pembelajaran Kooperatif Tipe Jigsaw pada Mata Pelajaran Kimia di Madrasah Aliyah. Lantanida Journal Vol 5 Nomor 1 hlm 13-28.

Dimyati \& Mudjiono. 2015. Belajar dan Pembelajaran. Jakarta : PT Rineka Cipta

Kusuma, Z. L., \& Subkhan, S. 2015. Pengaruh Motivasi Belajar dan Kedisiplinan Belajar terhadap Prestasi Belajar Mata Pelajaran Akuntansi Siswa Kelas XI IPS SMA N 3 Pati Tahun Pelajaran 2013/2014. Economic Education Analysis Journal Vol 4 Nomor 1.

Lestari, K. E. (2014). Implementasi Brain-Based Learning untuk meningkatkan kemampuan koneksi dan kemampuan berpikir kritis serta motivasi belajar siswa SMP. Judika (Jurnal pendidikan UNSIKA), Vol 2 Nomor 1

Neolaka, A \& Neolaka, G.A.A. 2017. Landasan Pendidikan Dasar Pengenalan Diri Sendiri Menuju Perubahan Hidup. Depok : Kencana

Riadi, Muchlisin. (2019). Karakteristik, Jenis dan Prosedur Penelitian Kualitatif. https://www.kajianpustaka.com/2019/04/karakteristik-jenis-dan-prosedur-penelitiankualitatif.html. (diakses pada 07 April 2019)

Rusman. 2016. Model-Model Pembelajaran Mengembangkan Profesionalisme Guru. Jakarta : PT Rajagrafindo Persada

Sugiyono. 2014 . Metode Penelitian Kuantitatif Kualitatif dan $R \&$ D, Bandung : Alfabeta

Suprihatin, S. (2015). Upaya guru dalam meningkatkan motivasi belajar siswa. Jurnal Pendidikan Ekonomi UM Metro, Vol 3 Nomor 1, hlm 73-82.

Undang-Undang Nomor 22 Tahun 2006 tentang Standar Isi untuk Satuan Pendidikan Dasar. 2006. Jakarta : Menteri Pendidikan Nasional. 